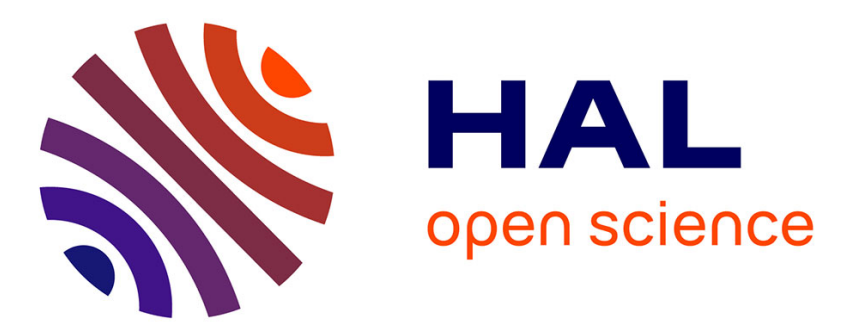

\title{
Protection Of Chemolithoautotrophic Bacteria Exposed To Simulated Mars Environmental Conditions
}

Felipe Gómez, Eva Mateo-Martí, Olga Prieto-Ballesteros, Jose Martín-Gago, Ricardo Amils

\section{- To cite this version:}

Felipe Gómez, Eva Mateo-Martí, Olga Prieto-Ballesteros, Jose Martín-Gago, Ricardo Amils. Protection Of Chemolithoautotrophic Bacteria Exposed To Simulated Mars Environmental Conditions. Icarus, 2010, 209 (2), pp.482. 10.1016/j.icarus.2010.05.027 . hal-00676214

\section{HAL Id: hal-00676214 https://hal.science/hal-00676214}

Submitted on 4 Mar 2012

HAL is a multi-disciplinary open access archive for the deposit and dissemination of scientific research documents, whether they are published or not. The documents may come from teaching and research institutions in France or abroad, or from public or private research centers.
L'archive ouverte pluridisciplinaire HAL, est destinée au dépôt et à la diffusion de documents scientifiques de niveau recherche, publiés ou non, émanant des établissements d'enseignement et de recherche français ou étrangers, des laboratoires publics ou privés. 


\section{Accepted Manuscript}

Protection Of Chemolithoautotrophic Bacteria Exposed To Simulated Mars Environmental Conditions

Felipe Gómez, Eva Mateo-Martí, Olga Prieto-Ballesteros, Jose Martín-Gago, Ricardo Amils

PII:

S0019-1035(10)00220-4

DOI:

10.1016/j.icarus.2010.05.027

Reference:

YICAR 9450

To appear in:

Icarus

Received Date:

11 August 2009

Revised Date:

14 May 2010

Accepted Date:

28 May 2010

Please cite this article as: Gómez, F., Mateo-Martí, E., Prieto-Ballesteros, O., Martín-Gago, J., Amils, R., Protection Of Chemolithoautotrophic Bacteria Exposed To Simulated Mars Environmental Conditions, Icarus (2010), doi: 10.1016/j.icarus.2010.05.027

This is a PDF file of an unedited manuscript that has been accepted for publication. As a service to our customers we are providing this early version of the manuscript. The manuscript will undergo copyediting, typesetting, and review of the resulting proof before it is published in its final form. Please note that during the production process errors may be discovered which could affect the content, and all legal disclaimers that apply to the journal pertain. 


\section{PROTECTION OF CHEMOLITHOAUTOTROPHIC BACTERIA EXPOSED TO SIMULATED MARS ENVIRONMENTAL CONDITIONS}

Felipe Gómez $^{1 *}$, Eva Mateo-Martí ${ }^{1}$, Olga Prieto-Ballesteros ${ }^{1}$, Jose Martín-Gago ${ }^{1}$, and Ricardo Amils ${ }^{1,2}$

${ }^{1}$ Centro de Astrobiología (CSIC-INTA), Carretera de Torrejón-Ajalvir, Km 4. Torrejón de Ardoz, 28850 Madrid (Spain) and ${ }^{2}$ Centro de Biología Molecular Severo Ochoa (UAM-CSIC), Universidad Autónoma de Madrid, Cantoblanco, 28049 Madrid (Spain)

* Corresponding Author

Address:

Felipe Gómez Gómez

Centro de Astrobiología (INTA-CSIC)

Intituto Nacional de Técnica Aerospacial

Carretera de Torrejón a Ajalyir Km. 4

Torrejón de Ardoz

Madrid 28850

Spain

e-mail: gomezgf@inta.es

Tel. 34915206461

Fax. 34915201074

Running Title: Subsurface Mars simulation environment.

Key Words: Mars; Mars, surface; Astrobiology; Regoliths; Acidophilic bacteria; Planetary atmospheres simulation chamber; 


\begin{abstract}
Current surface conditions (strong oxidative atmosphere, UV radiation, low temperatures and xeric conditions) on Mars are considered extremely challenging for life. The question is whether there are any features on Mars that could exert a protective effect against the sterilizing conditions detected on its surface. Potential habitability in the subsurface would increase if the overlaying material played a protective role. With the aim of evaluating this possibility we studied the viability of two microorganisms under different conditions in a Mars simulation chamber. An acidophilic chemolithotroph isolated from Río Tinto belonging to the Acidithiobacillus genus and Deinococcus radiodurans, a radiation resistant microorganism, were exposed to simulated Mars conditions under the protection of a layer of ferric oxides and hydroxides, a Mars regolith analogue. Samples of these microorganisms were exposed to UV radiation in Mars atmospheric conditions at different time intervals under the protection of 2 and $5 \mathrm{~mm}$ layers of oxidized iron minerals. Viability was evaluated by inoculation on fresh media and characterization of their growth cultures. Here we report the survival capability of both bacteria to simulated Mars environmental conditions.
\end{abstract}

\title{
Introduction
}

Scientists have long speculated about the possibility of life on Mars (Klein et al., 1976; McKay, 1997). Mariner 9, a 1970s NASA mission reported Martian images with topological signatures resembling lake structures and sedimentary deposits. These scenarios suggested interesting possibilities for the development of life on Mars, but a few years later the Viking Landers reported extremely harsh physico-chemical conditions on the surface of the planet which challenged those expectations (Klein, 1978). The odds for life on Mars changed again with the new data released by the Mars Global Surveyor, launched in 1996, and from the 2004 Mars Rovers Missions. The MER Opportunity landed in Meridiani Planum where sedimentary deposits have been identified in different craters (Squyres and Knoll, 2005).

The existence of extinct or extant liquid water in Mars subsurface would increase its habitability potential. Evidence of extant water on Mars was reported by the Mars Express mission (Poulet et al., 2005). OMEGA near-infrared spectrometer reported the presence of phyllosilicates on the Mars surface. These water bearing minerals located on early Mars surfaces are solid proof of the existence of water in early Mars. Other authors have recently reported a wider diversity of phyllosilicate mineralogy using the Compact Reconnaissance Imaging Spectrometer (CRISM) on the Mars Reconnaissance Orbiter (MRO) (Mustard et al., 2008). Other evidence of a wet past of Mars come from the Opportunity rover at Meridiani Planum. The identification of hematite, goethite and sulfate rich deposits, such as jarosite (Squyres et al., 2004), gave a possible scenario for a past aqueous acidic environment on Mars.

On Earth, life works as an environmental transformer (Gómez and Amils, 2002. Chemolithotrophic microorganisms are able to transform the environments in which they develop through homeostatic process (Fernández-Remolar et al., 2008a). These homeostatic mechanisms then generate environmental modifications (physical or chemical anomalies) that could be used as biosignatures on future Mars exploration 
missions (MSL or ExoMars). The presence of methane in the Mars atmosphere is an example of these chemical signatures that could be consistent with life. Some chemolithotrophic microorganisms are able to obtain energy using $\mathrm{H}_{2}$ as the electron donor and $\mathrm{CO}_{2}$ as an electron acceptor, producing $\mathrm{CH} 4$. Recently reported results about the presence of methane in the Martian atmosphere (Mumma et al., 2009) increased the astrobiological interest of putative protected ecosystems in the Mars subsurface. Methane has a short lifetime which means that actual identification requires active production or a reservoir large enough to maintain its presence in the atmosphere. If it is the result of biological activity this would mean extant subsurface life.

Mars and Earth might have had many similarities in their early histories. Although the subsequent evolution of both planets has been completely different, geological signatures on Mars' surface indicate the past existence of water on the red planet. Could the Martian sulfate and iron oxidized deposits detected there (Squyres and Knoll, 2005; Clark et al., 2005) be the result of acidic chemolithotrophic metabolism? Geological results from the MER rover, Opportunity, at Endurance Crater indicate a possible acidic environment in the origin of the observed geological deposits. Similar deposits are located around the Río Tinto source area as a product of chemolithotrophic metabolism of microorganisms thriving in the rich metal sulfidic deposits of the Iberian Pyritic Belt (Fernández-Remolar et al., 2005; Fernández-Remolar et al., 2008b). Further studies are required to determine whether life could take advantage of the potential protected Martian subsurface habitats.

Río Tinto is a 100km long extreme acidic environment located in the Southwestern part of the Iberian Peninsula (Amaral-Zettler et al., 2002; Gonzalez-Toril et al., 2003). The river rises in the heart of the Iberian Pyritic Belt, one of the biggest mineral sulfidic concentrations in the world. These conditions enable the establishment of an extreme iron controlled ecosystem (Amils et al., 2007). Such an extreme environment was though to be uninhabitable, but microbial ecology studies reported the presence of microorganisms belonging to the three domains of life (Amaral-Zettler et al., 2002). The system is sustained by the oxidation of iron sulfide (pyrite) by chemolithotrophic microorganisms (Acidithiobacillus ferrooxidans, Leptospirrillum spp.) (López-Archilla et al., 2001; Amaral-Zettler et al., 2002; González-Toril et al., 2003, Amils et al., 2008) leading to the generation of sulfate and ferric iron, which are responsible for the two main characteristic of the river: low $\mathrm{pH}$ and high metal content. Due to these chemical characteristics, iron oxides and ferric sulfates, including jarosite, are abundant in the Río Tinto basin (Fernández-Remolar et al., 2003; 2005). The historical geological record of the Río Tinto area with its ancient and modern iron deposits gave this ecosystem the status of terrestrial Mars analogue, with a mineral composition very similar to some regions of Mars (Fernández-Remolar et al., 2005; Fernández-Remolar et al., 2008b). Microorganisms involved in the iron and sulfur cycles are able to obtain energy coupling oxidizing and reducing reactions to the electron transport chain (Sand et al., 2001). Some of them need oxygen for their metabolism, but this is not a strict requirement, because others, such as Acidithiobacillus ferrooxidans, are able to use ferric iron as an electron acceptor in anaerobic conditions to obtain energy oxidizing reduced sulfur compounds.

Acidophiles from Río Tinto are suitable for the study of habitability under simulated Mars conditions due to its capability for using iron as electron donor and the mineralogical similarity between both places. Ultraviolet doses at short wavelength are 
too strong for life to develop on the surface of Mars (Schuerger et al., 2006). It is well established that some features, like ice or mineral components of rocks can efficiently protect cell systems from UV radiation (Olson and Pierson, 1986; Cleaves and Miller, 1998; García-Pitchel, 1998; Rothschild and Cockell, 1999; Phoenix et al., 2001; Bishop et al., 2006; Cockell et al., 2003). Recently, it has been shown that ferric iron in solution (Gómez et al., 2007) can protect sensitive algae from UV radiation. Previous reports evaluated the effects of different extreme Martian surface conditions on terrestrial microorganisms. Some authors studied the effects of only one stress condition: ultraviolet radiation (Elasri and Miller, 1999; Schuerger, et al., 2006), heavy ions (Baltschukat et al., 1986), simulated Mars solar radiation (Tauscher, et al., 2006), extreme dryness (Dose and Gill, 1995; Kendrick and Kral, 2006) or microgravity (Sugiura et al., 1999). Other authors studied the effect of more than one stress condition: Mars atmospheric pressure and composition (Nicholson and Schuerger, 2005), space vacuum and ultraviolet irradiation (Saffary et al., 2002), or the comparative effects of several stresses on vegetative cells and spores (Díaz and Schulze-Makuch, 2006; Dose and Klein, 1996).

Mars surface dust could also play a protective role. Some images from the MERs Opportunity and Spirit on the surface of Mars have reported highly dusty conditions (Fig. 1). Both rovers are sometimes coated by dust which is mobilized by winds or dust devils. Could dust protect life against radiation? To answer this question, we report here on our studies of protection by Río Tinto Basin iron oxides and hydroxides on two model microorganisms, Acidithiobacillus ferrooxidans, (an acidophile isolate from Río Tinto) and Deinococcus radiodurans under simulated Mars surface conditions, with stressing conditions operating at the same time. D. radiodurans is a well-known polyextreme resistant microorganism (Daly et al., 2004) used in this work as a reference system, and At. ferrooxidans is an acidophilic bacteria that could be able to develop in the geochemical conditions described in some Mars locations (Fernández-Remolar et al., 2005) with some restrictions due to iron oxidizers require oxygen, but Acidithiobacillus ferrooxidans is able to use ferric iron as an electron acceptor in anaerobic conditions.

\section{Materials and Methods}

\section{Microorganisms}

At. ferrooxidans isolate 3.2 was used in this study. It was isolated from Río Tinto 3.2 station by Dr. Moustafa Malki (Malki, M., 2003). At. ferrooxidans was grown in the conditions describe by González-Toril et al., 2006 in Mackintosh media (Mackintosh, M. E., 1978).

Deinoccocus radiodurans, a poly-extremophile microorganism, from the German culture collection DSMZ, cat. $\mathrm{n}^{\circ}$ 20539, was used as a reference system. This strain was grown in corynebacterium media (casein peptone tryptic digest $10 \mathrm{~g}$, yeast extract 5 $\mathrm{g}$, glucose $5 \mathrm{~g}, \mathrm{NaCl} 5 \mathrm{~g}$, distilled water $1000 \mathrm{ml}$, pH adjusted to 7.2 - 7.4). For solid media, $10 \mathrm{~g} / \mathrm{l}$ of Agar were added.

The inoculated fresh media were incubated at the optimal temperature for each microorganism $\left(30{ }^{\circ} \mathrm{C}\right.$ for both). At different time intervals microorganisms were 
filtered and cell number was determined by fluorescence microscopy after DAPI staining.

\section{Protecting cakes preparation}

A simulated protective subsurface environment was designed specifically for these experiments in the form of a two cake (one circular base and a second protective layer). Figure 2 shows the structure of the cakes. Vegetative cells from growing cultures at the stationary phase of At. ferrooxidans and $D$, radiodurans were harvested by centrifugation and deposited on the center of the circular base (4 mm thick). A second shielding layer ( 2 or $5 \mathrm{~mm}$ thick) was then compacted over the first one. Two sets of experiments of sample exposition to simulated Mars surface conditions (Mars atmosphere gas composition, pressure and UV irradiation) were carried out with different exposure times, 2 and 10 hours.

The material used for cake preparation was from a ferruginous deposit of Alto de la Mesa sampling station at Río Tinto, composed mainly of goethite and hematite minerals (Fernández-Remolar et al., 2005). Samples were ground in an agate mortar and pestle. Powder was sieved in order to select thin $100 \mu \mathrm{m}$ diameter mineral grains. Powdered minerals were compressed using $6 \mathrm{~mm}$ diameter moulds. Material on the mould was compacted with a SPECAC hydraulic press to a final pressure of 100 At for avoiding any loss of material due to vacuum but ensuring some permeability for sample exposition to environmental stressors. Circular $4 \mathrm{~mm}$ thick and $6 \mathrm{~mm}$ diameter bases were generated for microbial exposure. Two and $5 \mathrm{~mm}$ thick protecting layers were deposited over the biological component. These protecting layers were compacted in the same conditions as described above. After exposure the cake was used to inoculate the corresponding fresh media. Two trials of inoculation experiments after Martian conditions exposition were done. The plotted values in figures 5 and 6 represent the mean value and error bars indicate the range between minimum and maximum value.

\section{Planetary Atmospheres Simulation Chamber}

Mars simulation experiments were performed in an especially designed environmental planetary atmospheres simulation chamber (Fig. 3) at the Centro de Astrobiología (Madrid) (Mateo-Martí et al., 2006). Mars atmospheric composition was the following: $95 \% \mathrm{CO}_{2}, 2.7 \% \mathrm{~N}_{2}, 1.6 \% \mathrm{Ar}$ and $0.6 \% \mathrm{H}_{2} \mathrm{O}$ with a pressure of 7 mbars. Temperature was set at $150 \mathrm{~K}$ with the intention of simulating a very restrictive Martian environment. Ultraviolet radiation source was a Deuterium lamp with a dose emission of $30 \mathrm{~mW} \mathrm{~cm} \mathrm{~cm}^{-2}$ in the wavelength range of 200-400 nm. Fig. 4 shows the radiation spectrum of the lamp used in the experiments.

\section{Results and discussion}

Two different microorganisms, the acidophilic bacteria At. ferrooxidans and the radiation resistant bacteria $D$. radiodurans, were used to study survival capacity in a Mars subsurface analogue environment. To simulate the subsurface environment we designed a two-layer regolith cake as a protective environment. A bacterial pellet was placed between the two layers. In order to compare the protecting effect of the layers thickness, samples were exposed to Mars surface conditions at different protective depths inside the cake, at 2 and $5 \mathrm{~mm}$, of iron minerals. The cakes were exposed to 
Mars extreme conditions for different periods of time (doses), 2 and 10 hours. These time periods were selected in order to obtain accumulation doses equivalents to 0.5 and 2.6 Martian Sol (Sol = Martian day; 24 h 37 min) in the worst UV scenario (location 15 S and Ls 270) (Patel et al., 2002).

When an inoculum of At. ferrooxidans was exposed to Mars surface conditions under the protection of either a 2 or $5 \mathrm{~mm}$ thick regolith protecting layer, bacterial growth was observed in all conditions after reinoculation in fresh media (fig. 5). At. ferrooxidans growth was severely affected by the exposure conditions but $2 \mathrm{~mm}$ of regolith was sufficient to protect bacteria from harsh Mars conditions (Fig. 5). Increasing the thickness of the protecting sheet lowers the deleterious effect on the bacterial growth. 5 $\mathrm{mm}$ regolith protection gave higher growth rates than $2 \mathrm{~mm}$. When the slopes of the growth curves were compared, steeper slopes were observed with the thicker regolith protection layer (Table 1). In any case, a thickness of $2 \mathrm{~mm}$ of the shielding layer was enough to obtain a high survivability value $(40.77 \%$ of slope similarity with respect to the unexposed control sample). The slopes of the curves were lower when exposure to Mars conditions was longer. Bacterial survivability is lower at 2 (40.77\% and $48.50 \%$ for $2 \mathrm{~h}$ and $10 \mathrm{~h}$ of simulated Martian conditions exposition, respectably) than at $5 \mathrm{~mm}$ (48.50\% and $30.05 \%$ for 2 and $10 \mathrm{~h}$ ) of thickness layer protection (Fig. 5). Since 1 $\mathrm{mm}$ thickness is enough for screening UV radiation (Fig. 4) any indirect UV effects could be noticed as previously reported by Hansen et al., (2005) and Yen et al., (2000). Thus, the observed decrease in bacterial survivability at $2 \mathrm{~mm}$ with respect to $5 \mathrm{~mm}$ depth in the soil cannot be simply explained by direct UV effect. Following data reported by Yen et al., (2000), the observed lower recovery level of bacterial viability at $2 \mathrm{~mm}$ could be UV-induced by the production of superoxide ions that could penetrate in the soil under a simulated Martian atmosphere. Then, UV indirect effects could go deeper in the soil than direct UV radiation goes.

Deinococcus radiodurans was much less affected than At. ferrooxidans to exposure to Mars conditions, which is not surprising due to its well reported stress-resistance capability. Similar growth rates (Fig. 6) were obtained from the inocula exposed during 2 and 10 hours under the protection of 2 or $5 \mathrm{~mm}$ thick layers of regolith. $D$. radiodurans slopes for the inocula protected under 2 and $5 \mathrm{~mm}$ thick layer were similar to the slope of the unexposed control inocula (Table 2). It was not possible to compare the growth curve slopes of the two bacteria due to the differences in their duplication time.

Actual Mars surface environmental conditions can be considered extreme for terrestrial microorganisms. Not only irradiation conditions but low pressure, dehydration and temperature are extreme conditions that organisms must deal with on the surface of Mars. Recent studies have reported the possible existence of water in the Mars subsurface (Malin and Edgett, 2000; Armstrong et al., 2005). Life as we know it on Earth needs water for its development. Due to the harsh oxidative conditions on the surface of Mars and the possible presence of water on the subsurface, it seems reasonable to search for life under the surface. Subsurface habitats protect against radiation. Dartnell et al., (2007) modelled the surface and subsurface radiation on Mars and demonstrated that the protective shielding depends on depth and the nature of the regolith material. Three different regolith models were used to asses radiation decay vs. depth. Their results reported 4.5 meters for wet heterogeneous regolith and $7 \mathrm{~m}$ in the case of the pure ice to obtain a similar protection for life than $D$. radiodurans has. 
In our case, both the 2 and $5 \mathrm{~mm}$ thick regolith layers provided enough protection against radiation and Mars environmental conditions for bacteria to survive. These experiments clearly show that non-sporulating Gram negative microorganisms can retain viability with only a thin layer of iron minerals (fig. 7). This is the first time that a marked ability to survive Mars conditions is reported for acidophilic chemolithotrophic microorganisms. These are organisms that are able to develop in the ionic conditions detected in different Mars locations.

Real Martian surface conditions simulation is difficult due to technical limitations. Some previously published work in the field refers to simulation of one or two Martian surface conditions, but not all the Martian surface conditions at the same time (Diaz and Schulze-Makuch, 2006; Newcombe et al., 2005; Schuerger et al., 2006). Then, results comparison is difficult. Different authors have reported experiments using endospores of Gram positive bacteria (Nicholson and Schuerger, 2005; Tauscher et al., 2006). Cockell et al., 2005 reported $99 \%$ of cell viability loss after $30 \mathrm{~min}$ of exposition of Chroococcidiopsis sp. to an 8.5 mbar $99.99 \% \mathrm{CO}_{2}$ atmosphere. Schuerger et al., (2003) reported Bacillus endospores survival under Martian surface pressure using several Mars atmospheric compositions Here we reported the exposition of vegetative bacteria to several Martian surface simulation conditions (atmosphere composition, pressure, temperature, water vapour content and radiation conditions). We obtained a high percentage of survivability of vegetative bacteria in all the cases under the protection of very thin regolith layers.

The experiments reported here broaden the range of possibilities for extant life on Mars. A slim Mars regolith layer is enough to greatly reduce radiation doses and offers a shielding layer for microorganisms. Habitability increases under only a few millimetres of regolith protection. The absence of carbonates in Mars regolith allows us to speculate about the idea of a putative acidic ocean on early Mars (Fairén et al., 2004). This environment would have promoted the weathering of basalts leading to the liberation of iron and magnesium into the ocean. The oxidation of ferrous iron could drive further the acidification of the water. A similar extant model for this type of environment can be found in the Río Tinto basin. The chemical reactions in this ecosystem are promoted by chemolithotrophic bacteria leading to the acidification of the river waters. The microbial metabolic products: iron hydroxides and oxides and sulphate salts, such as jarosite, are easily located in the Río Tinto basin, and they were also identified by the MER missions on the Mars surface (Squyres et al., 2004). The resistance of At. ferrooxidans to extreme conditions like those existing on the Mars surface under the protection of a thin regolith layer produced by its metabolism establishes new perspectives in the possibility of a chemolithotrophic environment in a putative Mars subsurface habitat.

\section{Acknowledgments}

This study was funded by the project ESP2006-06640 from the Spanish Ministry of Education and Science and FEDER funds from the European Community. Authors thank C.A.B, and INTA for the continuous support to this work. Authors also would like to thank two anonymous referees for the improvement of the final version of this work.

\section{References}


Amaral Zettler L. A., Gómez F., Zettler E., Keenan B. G., Amils R. \& Sogin M. L. 2002 Eukaryotic diversity in Spain's river of fire. Nature 417, 137.

Amils, R., González-Toril, E., Fernández-Remolar, D., Gómez, F., Aguilera, A., Rodríguez, N., Malki, M., García-Moyano, A., González-Fairén, A., de la Fuente, V., Sanz, J.L. 2007 Extreme Environments as Mars Terrestrial Analogs: The Río Tinto case. Planet. Space Sci. 55 (3), 370-381

Amils, R., Fernández-Remolar, D.C., Gómez, F., González-Toril, E., Rodríguez, N., Briones, C., Prieto-Ballesteros, O., Sanz, J.L., Díaz, E., Stevens, T.O. Stoker, C.R. and MARTE team. 2008 Subsurface geomicrobiology of the Iberian pyritic belt. In: Microbiology of Extreme Soils. Springer Berlin Heidelberg Eds. Soil Biology Series Vol. 13 pp. 205-223 doi: 10.1007/978-3-540-74231-9_10

Armstrong, J.C., Titus, T. N., Kieffer, H. H. 2005 Evidence for subsurface water ice in Korolev crater, Mars. Icarus, 174, 360-372.

Baltschukat, K., Horneck, G., Bucker, H., Facius, R. and Schafer, M. 1986 Mutation induction in spores of Bacillus subtilis by accelerated heavy ions. Radiat. Environ. Biophys. 25 (3), 183-187.

Bishop J. L., Louris S. K., Rogoff D. A. \& Rothschild L. J. 2006 Nanophase iron oxides as a key ultraviolet sunscreen for ancient photosynthetic microbes. International Journal of Astrobiology 5, 1-12.

Clark, B.C., Morris, R.V., McLennan, S.M., Gellert, R., Jolliff, B., Knoll, A.H., Squyres, S.W., Lowenstein, T.K., Ming, D.W., Tosca, N.J., Yen, A., Christensen, P.R., Gorevan, S., Brückner, J., Calvin, W., Dreibus, G., Farrand, W., Klingelhoefer, G., Waenke, H., Zipfel, J., Bell III, J.F., Grotzinger, J., McSween, H.Y. and Rieder, R. 2005 Chemistry and mineralogy of outcrops at Meridiani Planum. Earth Planet. Sci. Lett. 240, 73-95.

Cleaves, H. J. and Miller, S. L.1998 Oceanic protection of prebiotic organic compounds from UV radiation. Proc. Natl. Acad. Sci. 95, 7260-7263.

Cockell, C., Rettberg, P., Horneck, G., Scherer, K. and Stokes, M.D. 2003 Measurements of microbial protection from ultraviolet radiation in polar terrestrial microhabitats. Polar Biol. 26, 62-69.

Cockell, C., Schuerger, A. C., Billi, D., Friedmann, E.I. and Panitz, C. 2005 Effects of a simulated Martian UV flux on the Cyanobacterium, Chroococcidiopsis sp. 029 Astrobiology 5 (2), 127-140.

Daly, M.J., Gaidamakova, E.K., Matrosova, V.Y., Vasilenko, A., Zhai, M., Venkateswaran, A., Hess, M., Omelchenko, M.V., Kostandarithes, H.M., Makarova, K.S., Wackett, L.P., Fredrickson, J.K. and Ghosal, D. 2004 Accumulation of $\mathrm{Mn}$ (II) in Deinococcus radiodurans facilitates gammaradiation resistance. Science 306, 1025-1028.

Dartnell, L.R., Desorgher, L., Ward, J.M. and Coates, A.J. 2007 Geophys. Res. Lett. 34, L02207, doi: 10.1029/2006GL027494.

Díaz, B. and Schulze-Makuch, D. 2006 Microbial survival rates of Escherichia coli and Deinococcus radiodurans under low temperature, low pressure, and UVirradiation conditions, and their relevance to possible Martian life. Astrobiology $6(2), 332-347$.

Dose, K. and Gill, M. 1995 DNA stability and survival of Bacillus subtilis spores in extreme dryness. Orig. Life Evol. Biosph. 25 (1-3), 277-93.

Dose, K. and Klein, A. 1996 Response of Bacillus subtilis spores to dehydration and UV irradiation at extremely low temperatures. Orig. Life Evol. Biosph. 26 (1), 47-59. 
Elasri, M. O. and Miller, R. V. 1999 Study of the response of a biofilm bacterial community to UV radiation. Appl. Env. Microbiol. 65 (5),2025-2031.

Fairén, A.G., Fernández-Remolar, D., Dohm, J.M., Baker, V.R. and Amils, R. 2004 Inhibition of carbonate synthesis in acidic oceans on early Mars. Nature 431, 423-426.

Fernández-Remolar D., Rodríguez N., Gómez F. \& Amils R. 2003 The geological record of an acidic environment driven by iron hydrochemistry: The Tinto River system. J. Geophys. Res. 108 (E7), 10.1029/2002JE001918.

Fernández-Remolar D. C., Morris R. V., Gruener J. E., Amils R. \& Knoll A. H. 2005 The Río Tinto Basin, Spain: Mineralogy, sedimentary geobiology, and implications for interpretation of outcrop rocks at Meridiani Planum, Mars. Earth Planet. Sci. Lett. 240 (1), 149-167.

Fernández-Remolar, D.C., Gómez, F., Prieto-Ballesteros, O., Schelble, R. T., Rodríguez, N. and Amils, R. 2008a Some ecological mechanisms to generate habitability in planetary subsurface areas by chemolithotrophic communities: The Río Tinto subsurface ecosystem as a model system. Astrobiology 8 (3), 157173.

Fernandez-Remolar, D. C., Prieto-Ballesteros, O., Rodriguez, N., Gomez, F., Amils, R., Gomez-Elvira, J. and Stoker, C. R. 2008b Underground habitats in the río Tinto basin: a model for subsurface life habitats on Mars. Astrobiology 8(5), 10231047. doi:10.1089/ast.2006.0104

García-Pichel, F. 1998 Solar ultraviolet and the evolutionary history of cyanobacteria. Origin. Life Evol. Biosph. 28, 321-347.

Gómez, F. and Amils R. 2002 Life as an environmental transformer. In: Evolving sun and its influence on planetary environments., Book Series: Astronomical Society of the Pacific Conference. Montesinos B; Gimenez A; Guinan EF. (Eds.) Vol. 269, pp. 339-352.

Gómez, F., Aguilera, A. and Amils, R. 2007 Soluble ferric iron as an effective protective agent against UV radiation: Implications for early life. Icarus 191, 352-359, doi: 10.1016/j.icarus.2007.04.008

González-Toril, E., Gómez, F., Rodríguez, N., Fernández-Remolar, D., Zuloaga, J., Marín, I. and Amils, P. 2003. Geomicrobiology of the Tinto River, a model of interest for biohydrometallurgy. Hydrometallurgy 71, 301-309.

González-Toril, E., Gómez, F., Malki, M. and Amils, R. 2006 Isolation and study of acidophilic microorganisms. In: "Methods in Microbiology", F. Rainey and A. Oren (Eds.), Elsevier, Oxford, Vol. 35, pp. 463-502.

Hansen, A. A., Merrison, J., Nørnberg, P., Lomstein, B. A. And Finster, K. 2005 Activity and stability of a complex bacterial soil community under simulated Martian conditons. Int. J. Astrobiol. 4 (2), 135-144.

http://marsrovers.jpl.nasa.gov/gallery/press/spirit/20050125a.html. 25 January 2005 NASA press release.

Kendrick G. M. and Kral A. T. 2006 Survival of Methanogens during desiccation: implications for life on Mars. Astrobiology 6 (4), 546-551.

Klein, H. P., Lederberg, J., Rich, A., Horowitz, N. H., Oyama, V. I. and Levin, G. V. 1976 The Viking mission: search for life on Mars. Nature 262, 24-27.

Klein, H. P. 1978 The Viking biological experiments on Mars. Icarus 34, 666-674.

López-Archilla A. I., Marín I., González A. \& Amils R. 2001 Microbial community composition and ecology of an acidic aquatic environment. Microb. Ecol. 41, 20-35. 
Mackintosh, M.E. 1978 Mackintosh, Nitrogen fixation by Thiobacillus ferrooxidans, J. Gen. Microbiol. 105, 215-218.

Malin, M.C. and Edgett, K.S. 2000 Evidence for recent groundwater seepage abd syrface runoff on Mars. Science 288, 2330-2335. doi: 10.1126/science.288.5475.233.

Malki, M. 2003 Acidithiobacillus ferrooxidans y su papel en la geomicrobiología del ciclo del hierro en el Río Tinto. In: PhD Thesis. Universidad Autonoma de Madrid.

Mateo-Martí, E., Prieto-Ballesteros, O., Sobrado, J.M., Gómez-Elvira, J. and MartínGago, J. 2006 A chamber for studying planetary environments and its applications to astrobiology. Measurement Science and Technology 17,1-7.

Mckay C. P. 1997 The search for Life on Mars. Orig. Life Evol. Biosph. 27(1 - 3), 263289.

Mumma, M. J., Villanueva, G. L., Novak, R. E., Hewagama, T., Bonev, B.P., DiSanti, M.A., Mandell, A. M., and Smith M.D. 2009 Strong release of methane on Mars in northern summer 2003. Science doi: 10.1126/science.1165243

Mustard, J F., Murchie, S L, Pelkey, S M, Ehlmann, B L, Milliken, R E, Grant, J A, Bibring, J-P, Poulet, F, Bishop, J, Dobrea, E N, Roach, L, Seelos, F, Arvidson, R E, Wiseman, S, Green, R, Hash, C, Humm, D, Malaret, E, McGovern, J A, Seelos, K, Clancy, T, Clark, R, Des Marais, D, Izenberg, N, Knudson, A, Langevin, Y, Martin, T, McGuire, P, Morris, R, Robinson, M, Roush, T, Smith, M, Swayze, G, Taylor, H, Titus, T, Wolff, M. 2008 Hydrated silicate minerals on Mars observed by the Mars Reconnaissance Orbiter CRISM instrument, Nature 454, 305 doi: 10.1038/nature07097

Newcombe, D.A., Schuerger, A.C., Benardini, J.N., Dickinson, D., Tanner, R. and Venkateswaran, K. 2005 Survival of spacecraft-associated microorganisms under simulated Martian UV irradiation. Appl. Environ. Microbiol. 71 (12), $8147-8156$

Nicholson, L. W. and Schuerger, C. S. 2005 Bacillus subtilis spore survival and expression of germination-induced bioluminescence after prolonged incubation under simulated Mars atmospheric pressure and composition : implications for planetary protection and lithopanspermia. Astrobiology 5 (4), 536-544.

Olson, J. M. and Pierson, B. K. 1986 Photosynthesis 3.5 thousand million years ago. Photosynthesis Research 9, 251-259.

Patel, M. R., Zarnecki, J. C. and Catling, D. C. 2002 Ultraviolet radiation on the surface of Mars and the Beagle 2 UV sensor. Planet. Space Sci. 50 (9), 915-927.

Phoenix, V. R., Konhauser, K. O., Adams, D. G. and Bottrell, S. H. 2001 Role of biomineralization as an ultraviolet shield: Implications for Archean life. Geology 29 (9), 823-826.

Poulet, F., Bibring, J. P., Mustard, J.F., Gendrin, A., Mangold, N., Langevin, Y., Arvidson, R.E., Gondet, B., Gómez, C., and The Omega Team. 2005 Phyllosilacates on Mars and Implications for Early Martian Climate. Nature 438, 623-627.

Rothschild, L. J., and Cockell, C. S. 1999 Radiation: microbial evolution, ecology, and relevance to Mars missions. Mutat. Res. 430 (2), 281-291.

Saffary, R., Nandakumar, R., Spencer, D., Robb, T. F., Davila, M. J., Swartz, M., Ofman, L., Thomas, J. R. and DiRuggiero, J. 2002 Microbial survival of space vacuum and extreme ultraviolet irradiation: strain isolation and analysis during a rocket flight. FEMS Microbiol. Lett. 215, 163-168. 
Sand, W., Gehrke, T., Jozsa, P-G. and Schippers, A. 2001 (Bio)chemistry of Bacterial Leaching-Direct vs. Indirect Bioleaching. Hydrometallurgy 59, 159-175.

Schuerger, A. C., Mancinelli, R. L., Kern, R. G., Rothschild, L. J. And McKay, C. P. 2003 Survival of endospores of Bacillus subtilis on spacecraft surfaces under simulated martian environments: implications for the forward contamination of Mars. Icarus 165, 253-276

Schuerger, A.C., Richards, J.T., Newcombe, D.A. and Venkateswaran, K. 2006 Rapid inactivation of seven Bacillus spp. Under simulated Mars UV irradiation. Icarus, 181 (1), 52-62. doi: 101016/j Icarus.2005.10.008.

Squyres S. W., Grotzinger J. P., Arvidson R. E., Bell J. F., III, Calvin W., Christensen P. R., Clark B. C., Crisp J. A., Farrand W. H., Herkenhoff K. E., Johnson J. R., Klingelhofer G., Knoll A. H., McLennan S. M., McSween H. Y., Jr., Morris R. V., Rice J. W., Jr., Rieder R. \& Soderblom L. A. 2004 In Situ Evidence for an Ancient Aqueous Environment at Meridiani Planum, Mars. Science 306 (5702), 1709-1714.

Squyres S. W. and Knoll A. H. 2005 Sedimentary rocks at Meridiani Planum: Origin, diagenesis, and implications for life on Mars. Earth Planet. Sci. Lett. 240 (1), 110.

Sugiura, K., Hashimoto, H., Ishikawa, Y., Kawasaki, Y., Kobayashi, K., Seki, K., Koike, J. and Saito, T. 1999 Cultivation of bacteria with ecological capsules in space. Adv. Space Res. 23 (2), 405-408.

Tauscher, C., Schuerger, C. A. and Nicholson, L. W. 2006 Survival and germinability of Bacillus subtilis spores exposed to simulated Mars solar radiation: implications for life detection and planetary protection. Astrobiology 6 (4), 592605.

Yen, A. S., Kim, S. S., Hecht, M. H., Frant, M. S. and Murray, B. 2000 Evidence that the reactivity of the Martian soil is due to superoxide ions. Science 289, 19091912. 


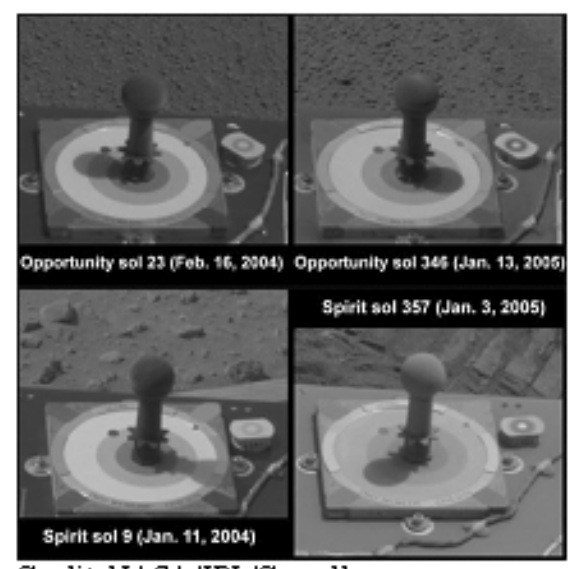

Credit: NASAIJPLIComell 


\section{circular base $(4 \mathrm{~mm})$}
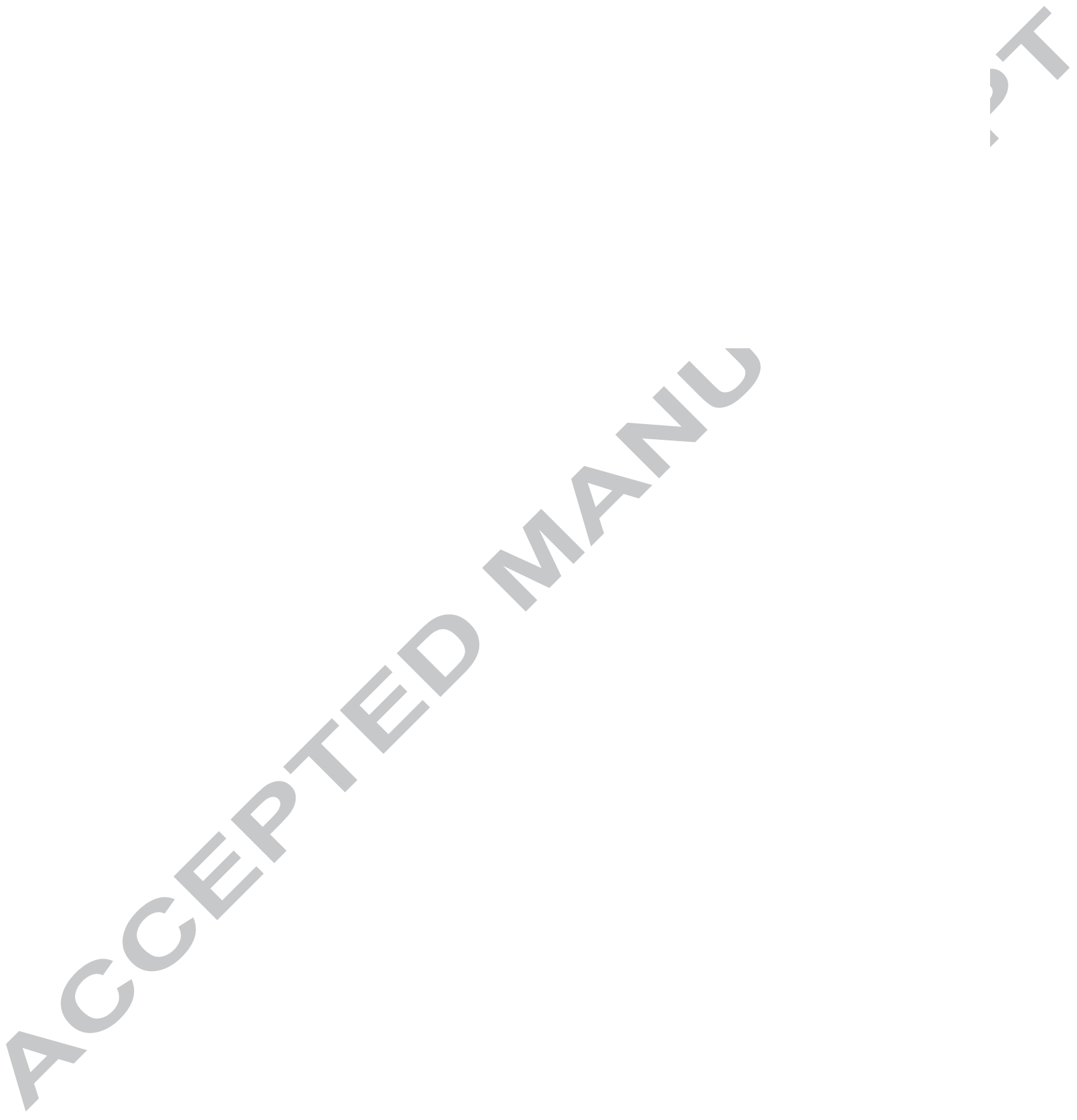


\section{ACCEPTED MANUSCRIPT}

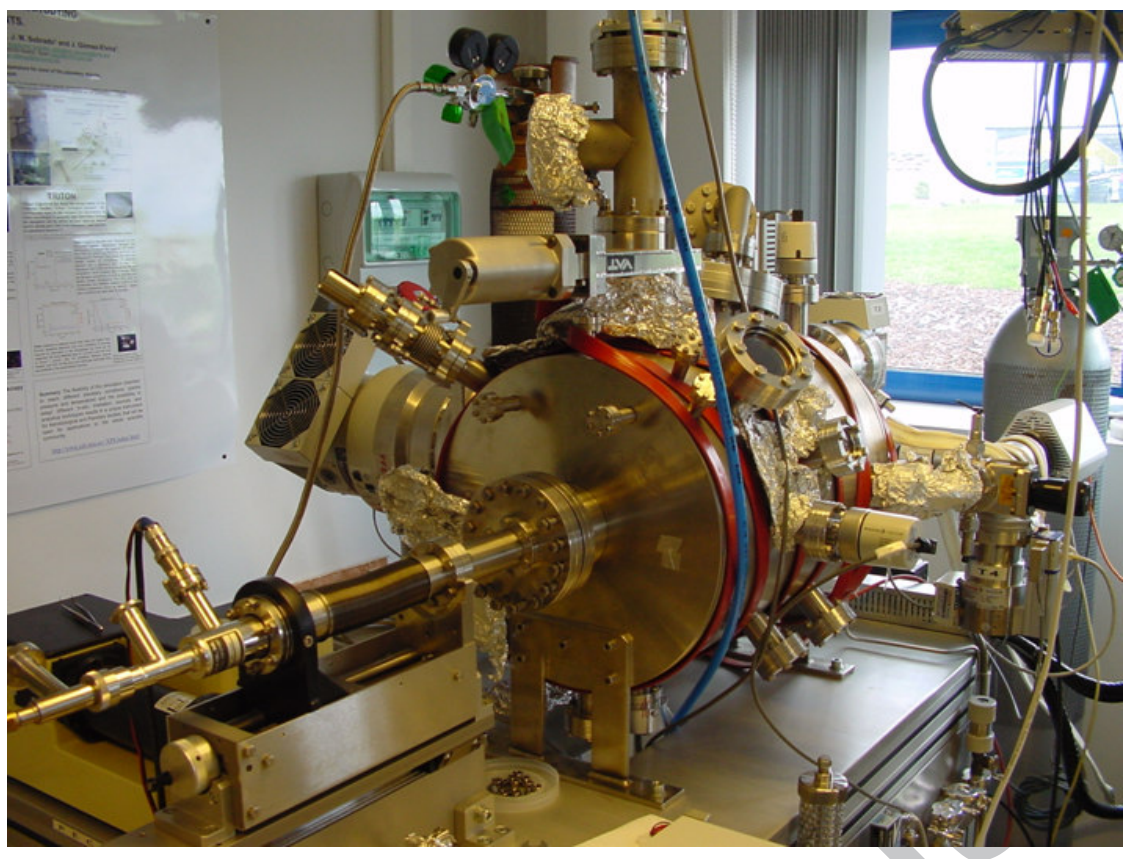




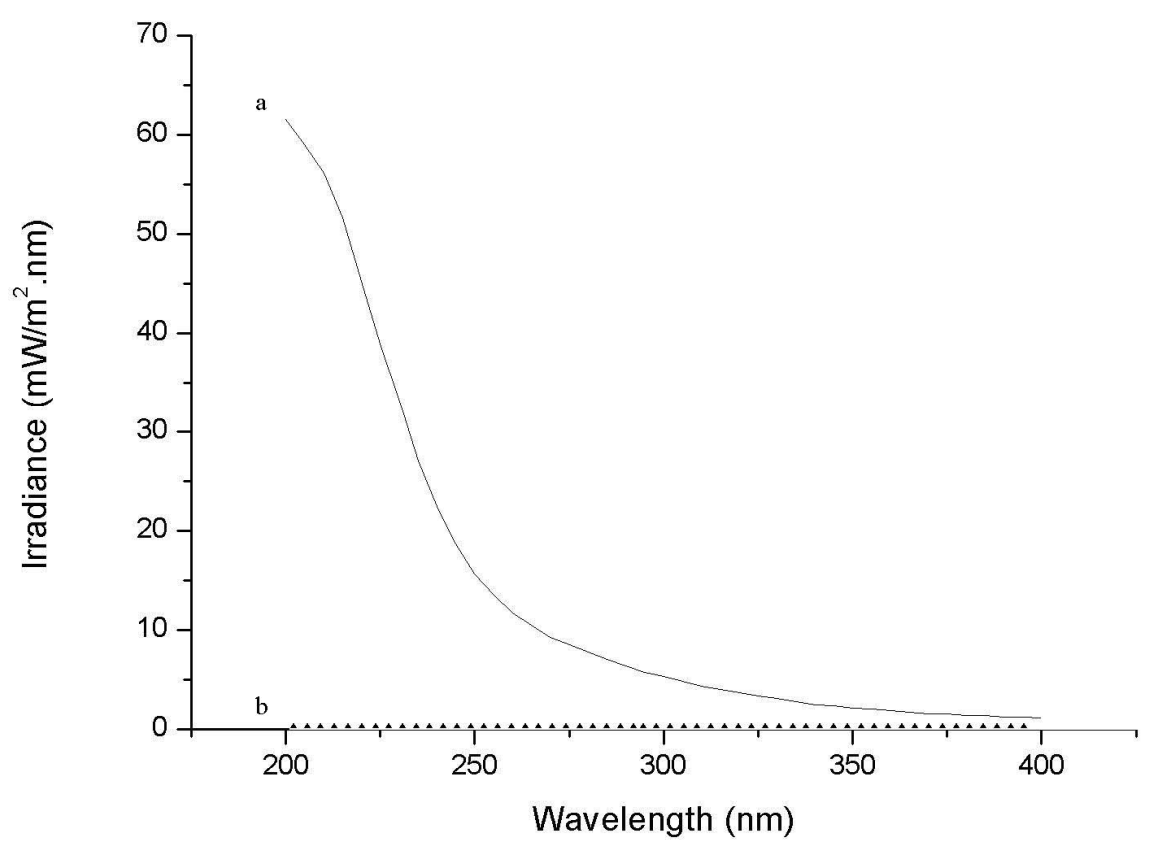



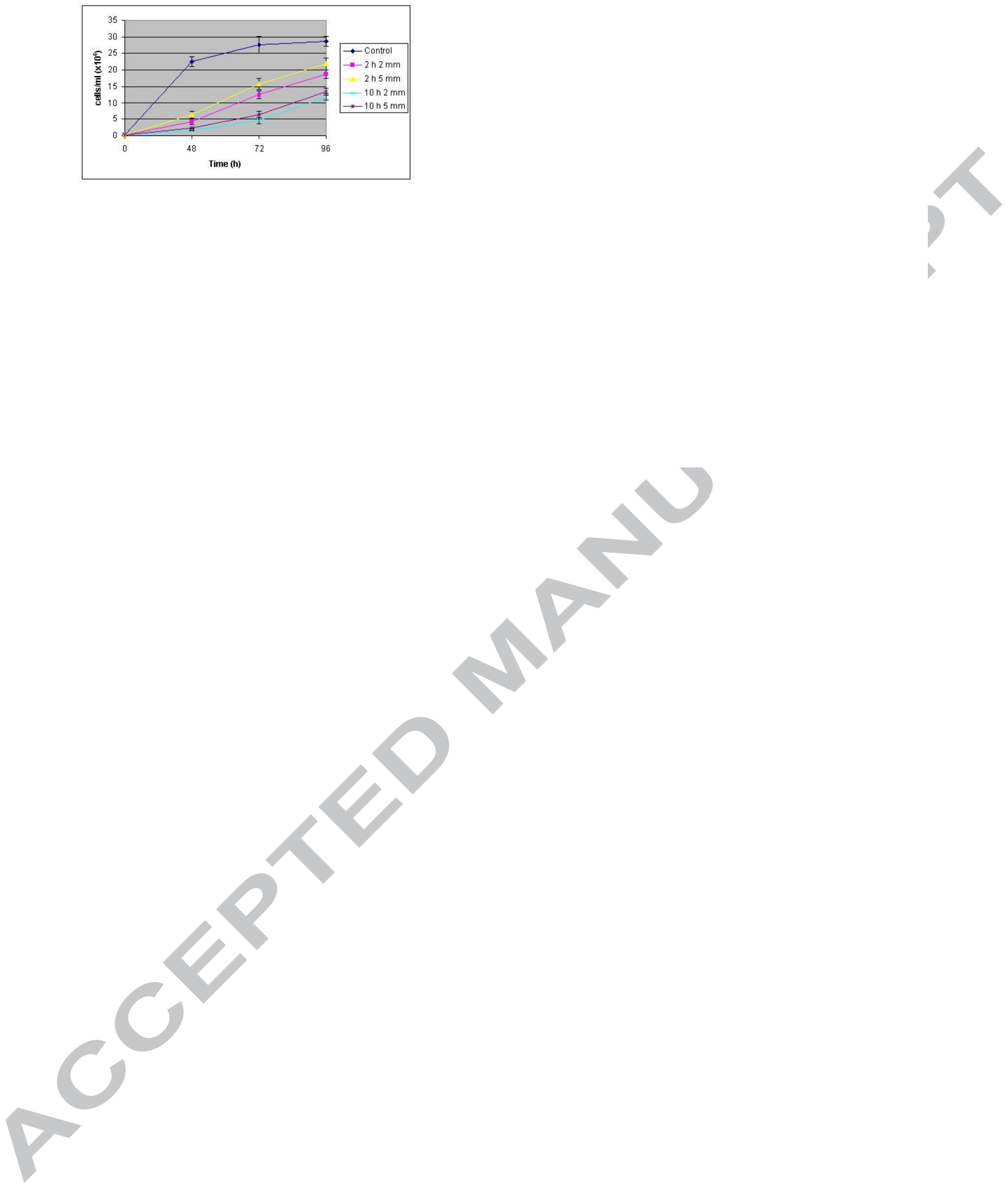

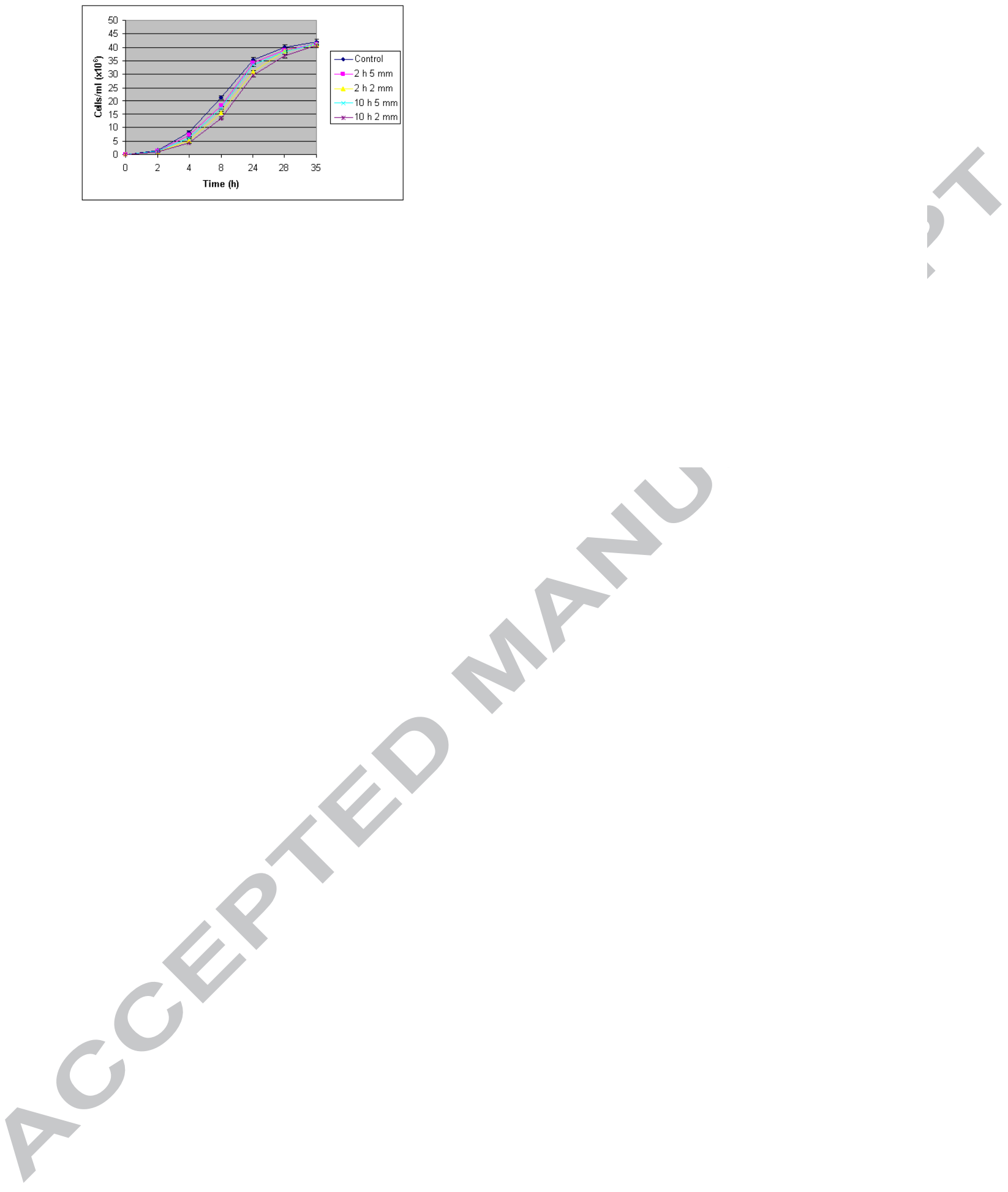


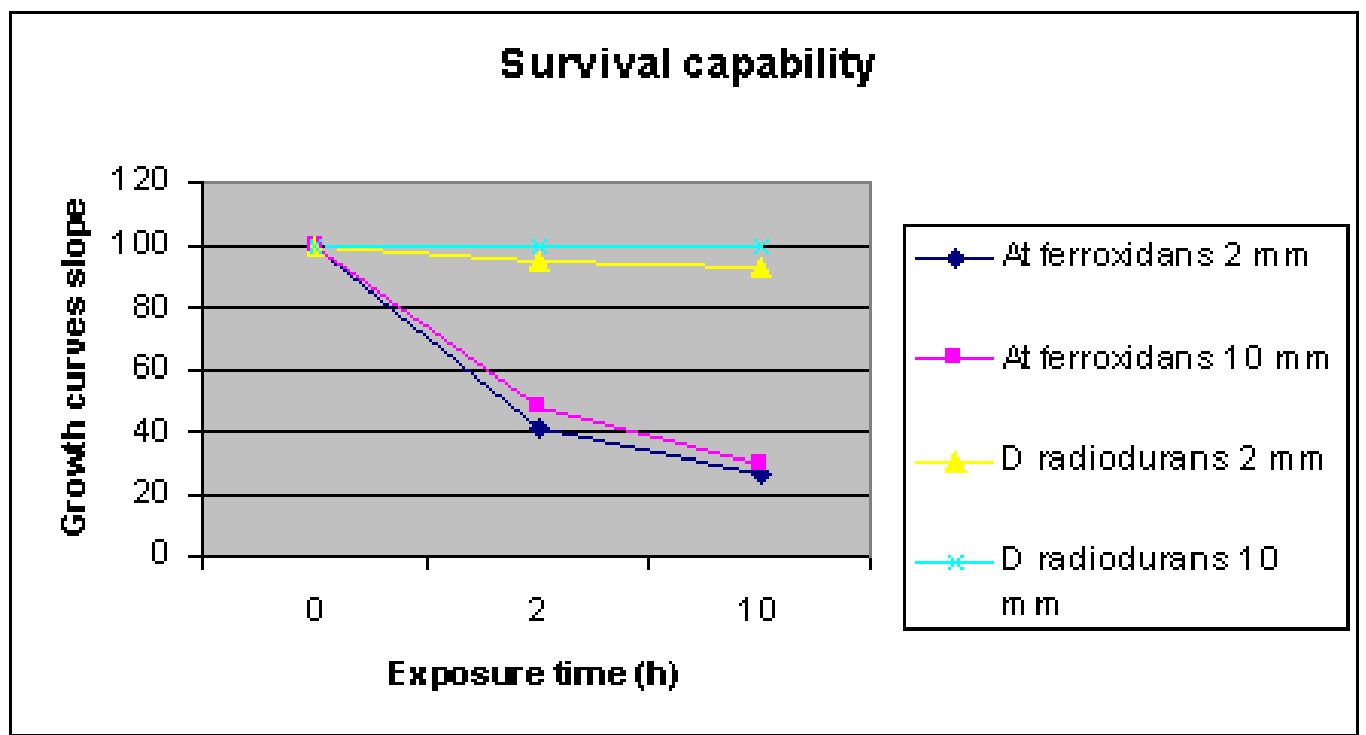


Credit: NASA/JPL/Cornell

Fig. 1: Panoramic camera's calibration target of Mars Environment Rover Spirit gradually covered by dust. The thickness of the dust layer was calculated to range between 1 to 10 micrometers. Spirit calibration target is the more dust-laden of the two rovers. As a result, a Spirit's power decrease has occurred due to the thin layer deposited on its solar panels.

(http://marsrovers.jpl.nasa.gov/gallery/press/spirit/20050125a.html)

Figure 2: Schematic diagram of the cakes used in the Mars environment simulation experiment. Cakes were made with Martian analogue regolith (see text for details).

Fig. 3: Photograph of the Planetary Simulation Camera used in this work.

Figure 4: a) Radiation spectrum of the deuterium lamp used in the Mars environment simulation experiment. The irradiance spectrum of the deuterium lamp is a continuum that decreases for increasing photon wavelength; it was monitored during irradiation using a spectroradiometer (Bentham DMc150FC), placed underneath the $\mathrm{CaF} 2$ window. b) Radiation spectrum under $1 \mathrm{~mm}$ layer thickness of soil used for the protection experiments. No UV penetration is clearly observed.

Figure 5: Protective effect of regolith on At. ferrooxidans after exposure to Mars environmental conditions for 2 and 10 hours of exposition and under $2 \mathrm{~mm}$ and $4 \mathrm{~mm}$ protecting layer thickness. Control: not exposed. The plotted values represent the mean value and error bars indicate the range between minimum and maximum value.

Figure 6: Growth curves of D. radiodurans after exposure to Mars conditions during 2 and 10 hours of exposition and under $2 \mathrm{~mm}$ and $4 \mathrm{~mm}$ protecting layer thickness. Control: not exposed. The plotted values represent the mean value and error bars indicate the range between minimum and maximum value.

Fig. 7: Percentage similarities of the growth curves slopes for both microorganisms exposed to different conditions with respect to unexposed inocula. The plotted values are mean values.

Table 1: Acidithiobacillus ferrooxidans growth curve slopes and percentage of similarities with the control culture (not exposed to Mars conditions).

Table 2: Deinococcus radiodurans growth curves slope and similarities, in percentage, with the control. 


\begin{tabular}{|l|l|l|}
\hline Time/depth exposition & Curve's slope $\left({\left.\mathrm{x} 10^{6}\right)}^{\text {\% in comparation with the }}\right.$ & $\begin{array}{l}\text { \% } \\
\text { control }\end{array}$ \\
\hline Control (not exposed) & 0.466 & $100 \%$ \\
\hline $2 \mathrm{~h} / 2 \mathrm{~mm}$ & 0.19 & $40.77 \%$ \\
\hline $2 \mathrm{~h} / 5 \mathrm{~mm}$ & 0.226 & $48.50 \%$ \\
\hline $10 \mathrm{~h} / 2 \mathrm{~mm}$ & 0.12 & $25.75 \%$ \\
\hline $10 \mathrm{~h} / 5 \mathrm{~mm}$ & 0.14 & $30.04 \%$ \\
\hline
\end{tabular}

Table 1: Acidithiobacillus ferrooxidans growth curve slopes and percentage of similarities with the control culture (not exposed to Mars conditions). 


\begin{tabular}{|l|l|l|}
\hline Time/depth exposition & Curve's slope $\left(\times 10^{6}\right)$ & $\begin{array}{l}\text { \% in comparation with the } \\
\text { control }\end{array}$ \\
\hline Control (not exposed) & 1.35 & $100 \%$ \\
\hline $2 \mathrm{~h} / 2 \mathrm{~mm}$ & 1.28 & $94.81 \%$ \\
\hline $2 \mathrm{~h} / 5 \mathrm{~mm}$ & 1.35 & $100 \%$ \\
\hline $10 \mathrm{~h} / 2 \mathrm{~mm}$ & 1.25 & $92.60 \%$ \\
\hline $10 \mathrm{~h} / 5 \mathrm{~mm}$ & 1.36 & $100 \%$ \\
\hline
\end{tabular}

Table 2: Deinococcus radiodurans growth curves slope and similarities, in percentage, with the control. 